\title{
Barysilite from Garpenberg Norra, Dalarna, Sweden: occurrence and crystal structure refinement
}

\author{
U. KOLITSCH ${ }^{1 * *}$ AND D. HOLTSTAM ${ }^{2}$ \\ ${ }^{1}$ Institut für Mineralogie und Kristallographie, Universität Wien, Geozentrum, Althanstr. 14, ^-1090 Wien, Austria \\ 2 Department of Mineralogy, Research Division, Swedish Museum of Natural History, Box 50007, SE-10405 \\ Stockholm, Sweden
}

\section{ABSTRACT}

A new occurrence of barysilite. $\mathrm{Pb}_{8} \mathrm{Mn}\left(\mathrm{Si}_{2} \mathrm{O}_{7}\right)_{3}$, at the polymetallic Garpenberg Norra $\mathrm{Zn}$ - $\mathrm{Pb}$ deposit, Hedemora. Dalarna, Sweden, is described. The mineral, which forms colourless, transparent grains, is characterized by X-ray diffraction and electron-microprobe analyses. The assemblage includes tephroite, zincian jacobsite, manganoan diopside and others. The crystal structure of a barysilite crystal from Garpenberg Norra was redetermined using single-crystal X-ray diffraction data (Mo- $K \alpha$, $C C D$ area detector) and has been refined in space group $R \overline{3} c$ with $a=9.804(1), c=38.416(8) \AA, V=$ $3197.8(8) \AA^{3}$, to $R 1=2.32 \%$ for 1025 'observed' reflections with $F_{0}>4 \sigma\left(F_{0}\right)$. A previous, lowprecision structure determination (Lajzérowicz, 1965; $R=20 \%$ ) is confirmed but improved considerably. The structure contains one distorted $\mathrm{MnO}_{6}$ polyhedron with six equivalent $\mathrm{Mn}-\mathrm{O}$ bonds $(2.224 \AA)$, one $\mathrm{Si}_{2} \mathrm{O}_{7}$ disilicate unit with an $\mathrm{Si}-\mathrm{O}-\mathrm{Si}$ angle of $120.9^{\circ}$, and two non-equivalent $\mathrm{Pb}$ sites. The $\mathrm{Pbl}$ site has a highly irregular, one-sided coordination with six $\mathrm{O}$ ligands, indicating a stereoactive $6 s^{2}$ lone-electron pair on the $\mathrm{Pb}^{2-}$ ion, whereas the $[6+3]$-coordinated $\mathrm{Pb} 2$ site is fairly regular, with $\mathrm{Pb}-\mathrm{O}$ distances of $2.540(3 \times), 2.674(3 \times)$ and $3.098(3 \times) \AA$. The $\mathrm{Pb} 2$ site contains $\sim 10 \%$ of $\mathrm{Ca}(+\mathrm{Ba})$ replacing $\mathrm{Pb}$, corresponding to the structural formula $\mathrm{Pb} 1_{6}(\mathrm{~Pb}, \mathrm{Ca}) 2_{2} \mathrm{Mn}\left(\mathrm{Si}_{2} \mathrm{O}_{7}\right)_{3}$. This is the first direct proof that not only the $M$ site in barysilite-type $\mathrm{Pb}_{8} M\left(\mathrm{Si}_{2} \mathrm{O}_{7}\right)_{3}$ compounds can be replaced by divalent cations.

KEYwORDs: barysilite, crystal structure, crystal chemistry, Garpenberg Norra, Sweden.

\section{Introduction}

BARYSILITE is a rare PbMn silicate first described by Sjögren and Lundström (1888) from the Harstigen mine, Filipstad, Värmland. Sweden. Later, it was also reported from the famous deposits Långban and Jakobsberg (both Filipstad, Sweden) and from Franklin, New Jersey, USA (Ito and Frondel, 1967; Dunn, 1985; Yeates, 1991, and references therein). Another occurrence of the mineral as minute tabular crystals, partly in association with cerussite, in a mining slag at the Glücksrad mine, Oberschulenberg, Harz mountains, Germany (Schellhorn, 1987; Wittern, 1994) is noteworthy.

\footnotetext{
* E-mail: uwe.kolitsch@univie.ac.at DOI: $10.1180 / 0026461026620034$
}

The correct chemical formula of barysilite was the subject of some considerable debate. First thought to be a pure lead silicate, the formulae $(\mathrm{Pb}, \mathrm{Mn}) \mathrm{Si}_{3} \mathrm{O}_{11}$ and $\mathrm{Pb}_{5} \mathrm{Mn}\left(\mathrm{Si}_{2} \mathrm{O}_{7}\right)_{2}$ were later suggested by Glasser (1964) and Ito and Frondel (1967), respectively. A low-precision singlecrystal structure solution of barysilite from Långban, Sweden, yielded the formula $\mathrm{Pb}_{8} \mathrm{Mn}\left(\mathrm{Si}_{2} \mathrm{O}_{7}\right)_{3}$, and showed the presence of one $\mathrm{Mn}$ and two $\mathrm{Pb}$ sites in the structure (Lajzérowicz, 1965; $a=9.821(5), c=38.38(6) \AA, V=$ $3205.9 \AA^{3}$, space group $R \overline{3} c, R=20 \%$ ). The divalent character of $\mathrm{Mn}$ in barysilite was confirmed by electron paramagnetic resonance (Michoulier, 1967). The structure of synthetic barysilite-type $\mathrm{Pb}_{3} \mathrm{Si}_{2} \mathrm{O}_{7}(a=10.126(3), c=$ $38.678(2) \AA, V=3434.8 \AA^{3}$ ) was reported by Petter et al. (1971) who referred to the compound as 'lead-barysilite' (see also Petter and Harnik, 


\section{U. KOLITSCH AND D. HOLTSTAM}

1971). Their single-crystal study $(R=4.2 \%)$ demonstrated that $\mathrm{Pb}$ substitutes for the $\mathrm{Mn}$, and that $\mathrm{Pb}_{3} \mathrm{Si}_{2} \mathrm{O}_{7}\left(=\mathrm{Pb}{ }_{8} \mathrm{~Pb}\left(\mathrm{Si}_{2} \mathrm{O}_{7}\right)_{3}\right)$ represents the $\mathrm{Pb}$ analogue of barysilite, $\mathrm{Pb}_{8} \mathrm{Mn}\left(\mathrm{Si}_{2} \mathrm{O}_{7}\right)_{3}$. Several authors obscrved that the $\mathrm{Mn}$ can be replaced by a larger number of divalent cations without any apparent change of crystal symmetry or space group (Lajzérowicz, 1965; Ito and Frondel, 1967; Billhardt, 1969; Bordeaux and Lajzérowicz, 1969; Harnik, 1972; Schmidt et al., 1982; Chen et al., 2001). Also, both complete and partial solid solution series with isotypic germanates were reported (Lajzérowicz, 1965; Bordeaux and Lajzérowicz, 1969; Salnikow et al., 1979; Schmidt et al., 1982, 1983; Otto, 1983; Firsov et al., 1984). Thus, the barysilite structure type apparently occurs for a large number of $\mathrm{Pb}_{8} M^{2+}\left(T_{2} \mathrm{O}_{7}\right)_{3}$ compounds with $M^{2+}=\mathrm{Be}, \mathrm{Mg}$, $\mathrm{Ca}, \mathrm{Mn}, \mathrm{Fe}, \mathrm{Co}, \mathrm{Ni}, \mathrm{Cu}, \mathrm{Zn}, \mathrm{Sr}, \mathrm{Ba}, \mathrm{Cd}$ or $\mathrm{Pb}$, and $T=\mathrm{Si}$ or Ge. Surprisingly, no crystal-structure refinements of any of these numerous compounds have been reported

The very high $R$-value $(20 \%)$ of the single previous structure determination of barysilite (Lajzérowicz, 1965), and incorrectly calculated metal-oxygen distances listed in that paper, suggested that a re-cxamination of the atomic structure of this mineral species was in order. A recent find of slightly calcian barysilite at Garpenberg Norra, Sweden, provided suitable material for this study. The present article reports and discusses a redetermination of the crystal structure of barysilite, and gives some details about the occurrence and paragenesis of the studied samples. We also performed studies on barysilite samples from both Harstigen and Långban by single-crystal methods, but none of them provided crystal fragments of suitable quality for structure determination.

\section{Occurrence and paragenesis}

The Garpenberg Norra mine in Hedemora, Dalarna, Sweden is part of the Garpenberg ore field which, along with the Zinkgruvan $\mathrm{Pb}-\mathrm{Zn}$ deposit in Askersund, Örebro, are the only deposits currently mined for base metals in the old mining superdistrict of central Sweden known as 'Bergslagen'. A good review of the metallogeny and volcanology of the Bergslagen district, including the Garpenberg ore field, is given in Allen $e$ t al. (1996). Garpenberg Norra is a $\mathrm{Zn}-\mathrm{Pb}$ (Fe-Mn-Cu-Sb-Ag) deposit associated with a marble unit, hosted by altered Svecofennian metavolcanic rocks, and which is also intersected by the mines of Garpenbergs Odalfält $3 \mathrm{~km} \mathrm{SW}$ of Garpenberg Norra. The sulphide ores, dominated by sphalerite, galena and pyrite, form lenses and veinlets in close association with dolomite marble and silicate skarns (Sandecki, 1983). Over the last 5 years some 20 species new to the deposit, and two new to science (rambergite; Kalinowski, 1996, and rinmanite; Holtstam et al., 2001), have been brought to light. Notable finds include alleghanyite, franklinite, harmotome, native $\mathrm{Pb}$, magnussonite, manganosite, melanotekite, pyroxmangite, pyrargyrite, roméite, samsonite, wenkite, willemite, yeatmanite and zincite. To date, $\sim 90$ mineral species have been identified from the Garpenberg Norra deposit (Grensman et al., 2001).

\section{Occurrence}

The samples originate from a dense skam rock of unusual composition from the $900 \mathrm{~m}$ level of the Garpenberg Norra mine, and were supposedly taken from the contact zone between the ores and the marble wall rock. They are dominated by dark grey tephroite with associated coarse-grained brownish green richterite; barysilite is confined to aggregates several $\mathrm{cm}$ wide, in which the proportion of the mineral may reach $>50 \%$. The individual, anhedral mineral grains, $\sim 2 \mathrm{~mm}$ in maximum dimension, are colourless and nearly transparent, with diamond lustre. The barysilite occurs in intimate association with tephroite, manganoan diopside and zincian jacobsite (Fig. 1). Phlogopite and native copper are subordinate components of the assemblage, and native $\mathrm{Pb}$ and its alteration products are occasionally seen as superficial coatings.

\section{Conditions of formation of barysilite}

At Franklin, New Jersey, barysilite is accompanied by willemite, hardystonite, nasonite (often in intimate association), ganomalite, margarosanite, manganaxinite and andradite (Shannon and Berman, 1926; Ito and Frondel, 1967; Dunn, 1985; Yeates, 1991). At Långban, the mineral was observed in association with barylite, manganoan diopside and garnet, but also in fissures and veins within cymrite-kentrolite and richterite-jacobsite skarns (Nysten et al., 1999), while at Harstigen, barysilite occurs associated with calcite and hedyphane in fissures hosted by garnet-tephroite skarns (Sjögren and Lundström, 1888). Barysilite 


\section{BARYSILITE FROM GARPENBERG NORRA}

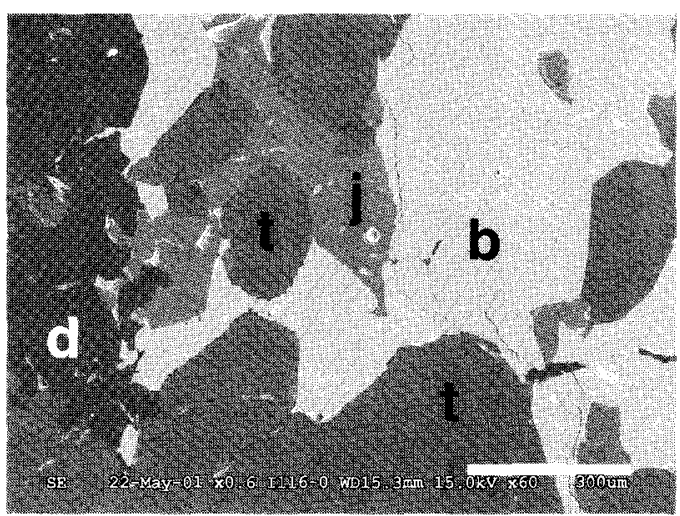

Fig. 1. Scanning electron micrograph of a polished rock scction containing barysilite (sample from Garpenberg Norra; Swedish Museum of Natural History catalogue no. $00+156) . b=$ barysilitc, $t=$ tephroite, $j=($ zincian $)$ jacobsite, $d=$ (manganoan) diopside. Scale bar is $0.3 \mathrm{~mm}$.

thus occurs in skarns formed at the climax of regional metamorphism, as well as in open late fractures and in slags. The conditions of peak metamorphism in the Garpenberg area have been determined as $T \geqslant 550^{\circ} \mathrm{C}$ and $P \leqslant 3.5 \mathrm{kbar}$ (Vivallo, 1984). Fluid-inclusion studies of fracture-hosted minerals at Lảngban suggest formation at low $T\left(<200^{\circ} \mathrm{C}\right)$ and $P$ close to atmospheric pressure (Jonsson and Broman, 1998). A reasonable conclusion from these observations is that the $T$ and $P$ are not critical factors for the formation of barysilite in a geological environment. It is noteworthy that all barysilite-bearing rocks reported are silica-undersaturated and devoid of sulphide minerals.

\section{Experimental}

\section{Chemical analysis}

The sample studied belongs to the collection of the Swedish Museum of Natural History, Stockholm (catalogue no. $00+156$ ). Quantitative wavelength-dispersive electron microprobe analyses (EMPA) of barysilite were carried out at $20 \mathrm{kV}$ and $15 \mathrm{nA}$, using a Cameca SX50 instrument. Complete analytical results are given in Table 1; the average of five analyses (wt.\%) is $\mathrm{PbO} 79.10, \mathrm{BaO} 0.44, \mathrm{MnO} 2.92, \mathrm{CaO} 0.44, \mathrm{MgO}$ $0.06, \mathrm{SiO}_{2}$ 16.16, $\mathrm{Al}_{2} \mathrm{O}_{3} 0.01$, total 99.13. $\mathrm{Na}, \mathrm{K}$, $\mathrm{Zn}, \mathrm{Ti}, \mathrm{Fe}$ and $\mathrm{Cl}$ were below the limit of detection $(\approx 0.05 \mathrm{wt} . \%)$. The material was found to be very homogeneous. An empirical formula based on $21 \mathrm{O}$ atoms is $\mathrm{Pb}_{7.88} \mathrm{Ba}_{0.06} \mathrm{Ca}_{0.18} \mathrm{Mn}_{0.92}$ $\mathrm{Si}_{5.98} \mathrm{O}_{21}$, corresponding to a slightly calcian (-barian) barysilite of idealized composition $(\mathrm{Pb}, \mathrm{Ca}, \mathrm{Ba})_{8} \mathrm{Mn}\left(\mathrm{Si}_{2} \mathrm{O}_{7}\right)_{3}$ (see also discussion below).

\section{Single-crystal $X$-ray studies}

Grain mounts of barysilite were studied using a polarized-light microscope. The grains are uniaxial negative but the studies also suggested that a very small deviation from optical uniaxiality could be present. No twinning was noted. Several optically homogeneous crystal fragments were mounted on a Nonius KappaCCD diffractometer equipped with a $300 \mu \mathrm{m}$ diameter capillary-optics collimator to provide increased resolution. Preliminary investigations consistently gave unit-cell parameters similar to those reported previously, and sharp diffraction maxima. Intensity data of a suitable crystal fragment

TABLE 1. Chemical analyses (EMP) of barysilite from Garpenberg Norra.

\begin{tabular}{|c|c|c|c|c|c|c|c|}
\hline Anal, no. & 1 & 2 & 3 & 4 & 5 & mean & $\sigma$ \\
\hline $\mathrm{PbO}$ & 79.33 & 79.78 & 78.75 & 78.37 & 79.26 & 79.10 & 0.49 \\
\hline $\mathrm{BaO}$ & 0.36 & 0.42 & 0.42 & 0.51 & 0.47 & 0.44 & 0.05 \\
\hline $\mathrm{MnO}$ & 3.05 & 2.77 & 2.84 & 3.07 & 2.88 & 2.92 & 0.12 \\
\hline $\mathrm{CaO}$ & 0.38 & 0.43 & 0.49 & 0.51 & 0.41 & 0.44 & 0.05 \\
\hline $\mathrm{MgO}$ & 0.08 & 0.03 & 0.06 & 0.06 & 0.05 & 0.06 & 0.02 \\
\hline $\mathrm{SiO}_{2}$ & 15.88 & 16.18 & 16.26 & 16.11 & 16.38 & 16.16 & 0.17 \\
\hline $\mathrm{Al}_{2} \mathrm{O}_{3}$ & 0.03 & 0.00 & 0.01 & 0.00 & 0.00 & 0.01 & 0.01 \\
\hline Sum & 99.11 & 99.61 & 98.84 & 98.63 & 99.46 & 99.13 & \\
\hline
\end{tabular}

EMP standards used: vanadinite $(\mathrm{Pb}-L \alpha)$, baryte $(\mathrm{Ba}-L \alpha), \mathrm{MnTiO}_{3}(\mathrm{Mn}-K \beta)$, wollastonite ( $\mathrm{Ca}-$ and $\mathrm{Si}-K \alpha), \mathrm{MgO}(\mathrm{Mg}-K \alpha), \mathrm{Al}_{2} \mathrm{O}_{3}(\mathrm{Al}-K \alpha)$ 


\section{U. KOLITSCH AND D. HOLTSTAM}

were collected at room temperature using $\mathrm{Mo}-\mathrm{K \alpha}$ radiation (see Table 2 for details). The measured data were processed using the Nonius program suite DENZO-SMN and corrected for Lorentz, polarization, background and absorption effects. Systematic extinctions and normalized structure factor statistics indicated the centrosymmetric space group $R \overline{3} c$.

The crystal structure was solved by direct methods (SHELXS-97, Sheldrick, 1997a) and yielded a model close to that of Lajzćrowicz (1965). Full-matrix least-squares refinement on $F^{2}$ (SHELXL-97, Sheldrick, 1997b) was carried out in space group $R \overline{3} c$. Conversion to anisotropic displacement parameters for the $\mathrm{Pb}$ and $\mathrm{Mn}$ atoms resulted in a preliminary $R 1$ index of $\sim 2.4 \%$. At this stage, occupancy refinements indicated that the $\mathrm{Pbl}, \mathrm{Mn}$ and $\mathrm{Si}$ sites were fully occupicd but that one or more lighter atoms were present on the $\mathrm{Pb} 2$ site (see further discussion below). Based on the chemical analysis, Ca was assumed to substitute for $\mathrm{Pb} 2$. The occupancy was refined accordingly, resulting in a $\mathrm{Pb} 2: \mathrm{Ca}$ ratio of $0.909(3): 0.091$, in good agreement with the EMPA data. The final $R 1$ index was $2.32 \%$ for 1025 'observed' reflections with $F_{\mathrm{o}}>4 \sigma\left(F_{0}\right)$ and 35 refined parameters $(\mathrm{w} R 2=5.55 \%)$. Maximum peaks in the final difference-Fourier maps were 2.27 and $-2.30 \mathrm{e} / \AA^{3}$, respectively. Because the optical properties of the sample suggested the possibility of a lower symmetry, the structure was also solved and refined in space group $C 2 / \mathrm{c}$. A higher final $R 1$ index, $3.6 \%$, and problems with anisotropic refinement of some of the non-O atoms clearly indicated that the correct space group is $R \overline{3} c$. The final positional and displacement parameters are given in Table 3. Selected bond lengths and angles, and calculated bondvalence sums are listed in Table 4 . Lists of observed and calculated structure factors have

TABLE: 2. Crystal data, data collection information and refinement details for barysilite from Garpenberg Norra.

Crystal data

Formula, space group

a, $c^{\prime}(\AA)$

$V\left(\AA^{3}\right), Z$

$F(000), \rho_{\text {calc }}\left(\mathrm{g} \mathrm{cm}^{-3}\right)$

$\mu\left(\mathrm{mm}^{-1}\right)$

Absorption correction

Crystal dimensions $(\mathrm{mm})$

Data collection and refinement

Diffractometer

$\lambda(\mathrm{Mo}-K \alpha)(\AA), T(\mathrm{~K})$

Detector-crystal dist. (mm)

Rotation axis; rot. width ()

Total no. of frames

Collection time per frame $(\mathrm{s})$

Collection mode, $2 \theta_{\max }(")$

$h, k, l$ ranges

Total reflections measured

Unique reflections

$R 1(F), \mathrm{w} R 2\left(F^{2}\right)^{*}$

Obscrved reflections $\left[F_{0}>4 \sigma\left(F_{0}\right)\right]$

Extinction coefficient

No. of refined parameters

GoF

$(\Delta / \sigma)_{\max }$

$\Delta \rho_{\min }, \Delta \rho_{\max }\left(\mathrm{e} / \AA^{3}\right)$
$\mathrm{Pb} \mathrm{Mn}_{8} \mathrm{M}\left(\mathrm{Si}_{2} \mathrm{O}_{7}\right)_{3}, R \overline{3} \mathrm{C}$

$9.804(1), 38.416(8)$

$3197.8(8) .6$

$5530,6.812$

62.54

multi-scan (Otwinowski and Minor, 1997)

$0.06 \times 0.08 \times 0.13$

Nonius KappaCCD system
$0.71073,293$
30
$\varphi, \omega ; 1.0$
522
300
sphere, 59.86
$-13 \rightarrow 12,-11 \rightarrow 13,-53 \rightarrow 53$
9178
1036
$2.32 \%, 5.55 \%$
1025
$0.000145(8)$
35
1.255
0.0001
$-2.30,2.27$

Unit-cell parameters were refined from nearly all recorded reflections

Scattering factors for neutral atoms were employed in the refinement

$*_{\mathrm{W}}=1 /\left[\sigma^{2}\left(F_{0}{ }^{2}\right)+(0.0 \mathrm{P})^{2}+130 \mathrm{P}\right] ; \mathrm{P}=\left(\left[\max\right.\right.$ of $\left(0\right.$ or $\left.\left.\left.F_{n}{ }^{2}\right)\right]+2 F_{i}{ }^{2}\right) / 3$ 


\section{BARYSILITE FROM GARPENBERG NORRA}

TABIE 3. Fractional atomic coordinates and displacement parameters $\left(\AA^{2}\right)$ for barysilite from Garpenberg Norra.

\begin{tabular}{|c|c|c|c|c|c|c|}
\hline Atom & $x$ & $y$ & $z$ & $U_{\text {eq }} / U_{\text {isl }}$ & & \\
\hline $\mathrm{Pbl}$ & $0.25627(3)$ & $0.23661(3)$ & $0.039503(6)$ & $0.00562(12)$ & & \\
\hline $\mathrm{Pb} 2 *$ & 0.0 & 0.0 & $0.162640(10)$ & $0.00605(17)$ & & \\
\hline $\mathrm{Mn}$ & 0.0 & 0.0 & 0.25 & $0.0027(4)$ & & \\
\hline $\mathrm{Si}$ & $0.59781(19)$ & $0.60219(19)$ & $0.04882(4)$ & $0.0010(3)$ & & \\
\hline 01 & $0.6129(6)$ & 0.0 & 0.25 & $0.0034(11)$ & & \\
\hline $\mathrm{O} 2$ & $0.6230(6)$ & $0.7148(6)$ & $0.01576(12)$ & $0.0100(9)$ & & \\
\hline $\mathrm{O} 3$ & $0.7069(5)$ & $0.5215(5)$ & $0.04550(11)$ & $0.0040(8)$ & & \\
\hline $\mathrm{O} 4$ & $0.4142(6)$ & $0.4768(6)$ & $0.05626(11)$ & $0.0085(9)$ & & \\
\hline Atom & $U_{11}$ & $U_{22}$ & $U_{33}$ & $U_{23}$ & $U_{13}$ & $U_{12}$ \\
\hline $\mathrm{Pbl}$ & $0.00412(16)$ & $0.00347(16)$ & $0.00719(16)$ & $-0.00086(7)$ & $-0.00097(8)$ & $0.00033(10)$ \\
\hline $\mathrm{Pb} 2 *$ & $0.00610(19)$ & $0.00610(19)$ & $0.0059(2)$ & 0.0 & 0.0 & $0.00305(10)$ \\
\hline $\mathrm{Mn}$ & $0.0020(6)$ & $0.0020(6)$ & $0.0040(9)$ & 0.0 & 0.0 & $0.0010(3)$ \\
\hline
\end{tabular}

* Refined occupancy: $\mathrm{Pb}_{0.909(3)} \mathrm{Ca}_{0.091}$

been deposited with the Principal Editor of Mineralogical Magazine and are available upon request. They are also available in the electronic version of the paper (see www minersoc.org).

TABLI: 4. Selected bond distances ( $⿱ \AA 2)$, angles ( ) and calculated bond valcnces (v.u.) for the coordination polyhedra in barysilite from Garpenberg Norra.

\begin{tabular}{|c|c|c|c|c|c|}
\hline $\mathrm{Pbl}-\mathrm{O} 4$ & $2.170(5)$ & 0.655 & $\mathrm{Mn}-\mathrm{O} 3 \times 6$ & $2.224(4)$ & $\underline{0.309} \times 6$ \\
\hline$-\mathrm{O} 2$ & $2.360(5)$ & 0.445 & $<\mathrm{Mn}-\mathrm{O}>$ & 2.22 & $\overline{2.85}$ v.u \\
\hline-03 & $2.479(4)$ & 0.349 & & & \\
\hline$-\mathrm{O} 2$ & $2.747(5)$ & 0.202 & $\mathrm{Si}-\mathrm{O} 4$ & $1.618(5)$ & 1.016 \\
\hline$-\mathrm{O} 4$ & $2.778(4)$ & 0.190 & $-\mathrm{O} 2$ & $1.619(5)$ & 1.014 \\
\hline-01 & $3.092(5)$ & $\underline{0.10}$ & -03 & $1.622(5)$ & 1.005 \\
\hline$\langle\mathrm{Pbl}-\mathrm{O}\rangle$ & {$[6]: 2.60$} & $\overline{1.94}$ v.u & $\begin{array}{r}-\mathrm{Ol} \\
\langle\mathrm{Si}-\mathrm{O}>\end{array}$ & $\begin{array}{l}1.666(3) \\
1.63\end{array}$ & $\frac{0.893}{3.93 \text { v.u. }}$ \\
\hline
\end{tabular}

\begin{tabular}{|c|c|c|c|c|}
\hline $\mathrm{Pb} 2-\mathrm{O} 3 \times 3$ & $2.540(4)$ & $0.308 \times 3$ & & \\
\hline$-02 \times 3$ & $2.674(5)$ & $0.234 \times 3$ & \multicolumn{2}{|c|}{ Bond-valence sums for the $O$ atoms are } \\
\hline$-04 \times 3$ & $3.098(5)$ & $0.099 \times 3$ & & $01234=193 \quad 190197 \quad 187 \mathrm{v}$ \\
\hline$\langle\mathrm{Pb} 2-\mathrm{O}\rangle$ & $\begin{array}{l}{[6+3]:} \\
2.61+3.10 \\
{[9]: 2.77}\end{array}$ & $\overline{1.92}$ v.u. & $01,2,3,4$ & $.90 .1 .97,1.87$ v.u. \\
\hline $\mathrm{O} 2-\mathrm{Si}-\mathrm{O} 4$ & $112.9(3)$ & & $\mathrm{O} 3-\mathrm{Mn}-\mathrm{O} 3 \times 3$ & $119.5(2)$ \\
\hline $\mathrm{O} 2-\mathrm{Si}-\mathrm{O} 3$ & $111.0(2)$ & & $\mathrm{O} 3-\mathrm{Mn}-\mathrm{O} 3 \times 6$ & $81.89(17)$ \\
\hline $\mathrm{O} 4-\mathrm{Si}-\mathrm{O} 3$ & $113.4(2)$ & & $\mathrm{O} 3-\mathrm{Mn}-\mathrm{O} 3 \times 3$ & $84.4(2)$ \\
\hline $\mathrm{O} 2-\mathrm{Si}-\mathrm{O} 1$ & $106.2(3)$ & & $\mathrm{O} 3-\mathrm{Mn}-\mathrm{O} 3 \times 2$ & $152.5(2)$ \\
\hline $\mathrm{O} 4-\mathrm{Si}-\mathrm{O} 1$ & $107.34(18)$ & & & \\
\hline $\mathrm{O} 3-\mathrm{Si}-\mathrm{OI}$ & $105.4(2)$ & & & \\
\hline$\langle\mathrm{O}-\mathrm{Si}-\mathrm{O}\rangle$ & 109.4 & & & \\
\hline
\end{tabular}

The bond-valence parameters used are from Brese and O'Keeffe (1991), and from Krivovichev and Brown (2001) for the $\mathrm{Pb}-\mathrm{O}$ bonds. The minor substitution of $(\mathrm{Ca}+\mathrm{Ba})$ for $\mathrm{Pb} 2$ has been ignored in these calculations 


\section{U. KOLITSCH AND D. HOLTSTAM}

\section{Results and discussion}

\section{Structure determination}

The redetermination of the crystal structure of barysilite, $\mathrm{Pb}_{8} \mathrm{Mn}\left(\mathrm{Si}_{2} \mathrm{O}_{7}\right)_{3}$, confirms the basic atomic arrangement found in the previous lowprecision study (Lajzérowicz, 1965; space group $R \overline{3} c, R=20 \%)$. However, our results $(R 1=$ $2.32 \%$ ) provide much more precise values for atomic coordinates, bond lengths and angles (see also below). The structure type is identical to that of synthetic $\mathrm{Pb} 8 \mathrm{~Pb}\left(\mathrm{Si}_{2} \mathrm{O}_{7}\right)_{3}\left(=\mathrm{Pb}_{3} \mathrm{Si}_{2} \mathrm{O}_{7}\right)$ (Petter et al., 1971; Petter and Harnik, 1971). [Note that the standardized coordinates for $\mathrm{O}(1)$ given in the original publication on synthetic $\mathrm{Pb} 8 \mathrm{~Pb}\left(\mathrm{Si}_{2} \mathrm{O}_{7}\right)_{3}$ (Petter et al., 1971) and also incorporated in the ICSD database are incorrect; the non-standard coordinates listed by Petter et al. (1971) are correct, however.]

\section{Coordination polyhedra and cationic substitutions}

The structure contains two non-equivalent $\mathrm{Pb}$, one $\mathrm{Mn}$, one $\mathrm{Si}$ and four $\mathrm{O}$ sites. The $\mathrm{Si}$ is tetrahedrally coordinated by $\mathrm{O}$ atoms at distances between $1.618(5)$ and $1.666(3) \AA$. These distances are very similar to the corresponding ones in synthetic $\mathrm{Pb}_{8} \mathrm{~Pb}\left(\mathrm{Si}_{2} \mathrm{O}_{7}\right)_{3} \quad(1.612$ and $1.666 \AA$, Petter et al., 1971). The range given in the previous structure determination by Lajzérowicz (1965), 1.56-1.63 $\AA$, is considerably different (note that these values were recalculated; the originally given values are, as already mentioned, incorrect).

Two $\mathrm{SiO}_{4}$ tetrahedra share the $\mathrm{Ol}$ atom to form isolated $\mathrm{Si}_{2} \mathrm{O}_{7}$ disilicate groups with a non-linear $\mathrm{Si}-\mathrm{O}-\mathrm{Si}$ axis. As is common for disilicate groups, the longest $\mathrm{Si}-\mathrm{O}$ bond is that involving the bridging oxygen $(\mathrm{Ol})$. The refined $\mathrm{Si}-\mathrm{O}-\mathrm{Si}$ angle, $120.9(4)$, is considerably different from the value 144 "calculated from the atomic coordinates given by Lajzérowicz (1965) (the originally given value, 133 , is incorrect), but close to the angle in synthetic $\mathrm{Pb} 8 \mathrm{~Pb}\left(\mathrm{Si}_{2} \mathrm{O}_{7}\right)_{3}$, 125.2 (Petter et al., 1971). As shown by Lajzérowicz (1965), this value is also influenced by cationic substitution for the $\mathrm{Pb}^{2-}$ and $\mathrm{Mn}^{2-}$ ions (see below). $\mathrm{O}-\mathrm{Si}-\mathrm{O}$ angles range between $105.4(2)$ and $113.4(2)^{\circ}$, with an average of 109.4

$\mathrm{Mn}^{2+}$ forms a $\mathrm{MnO}_{6}$ polyhedron with six equivalent $\mathrm{Mn}-\mathrm{O}$ bonds of length 2.224(4) $\AA$, but with a distorted geometry (range of $\mathrm{O}-\mathrm{Mn}-\mathrm{O}$ angles: $81.89(17)$ to $\left.152.5(2)^{\circ}\right)$ similar to that of a slightly twisted trigonal 'prism' (Fig. 2). The very minor Mg contents detected by EMPA $(0.06 \mathrm{wt} \%)$ suggest a very minor substitution of $\mathrm{Mn}$ by $\mathrm{Mg}$; occupancy refinements of the $\mathrm{Mn}$ site provided no evidence of any non-negligible $\mathrm{Mg}$ substitution. Two adjacent corners of the $\mathrm{MnO}_{6}$ are shared with the $\mathrm{Si}_{2} \mathrm{O}_{7}$ group (Fig. 2). In synthetic $\mathrm{Pb}_{8} \mathrm{~Pb}\left(\mathrm{Si}_{2} \mathrm{O}_{7}\right)_{3}$, the corresponding $\mathrm{PbO}_{6}$ polyhedron exhibits six equivalent $\mathrm{Pb}-\mathrm{O}$ bonds of length $2.50 \AA$ (Petter et al., 1971).

The first of the two non-equivalent $\mathrm{Pb}$ sites, $\mathrm{Pbl}$, has a highly irregular, one-sided coordination with six $\mathrm{O}$ ligands $(\mathrm{Pb}-\mathrm{O}$ range: $2.170(5)-3.092(5) \AA$ ), evidencing a very strong stereochemical influence of the $6 s^{2}$ lone-electron pair on the $\mathrm{Pb}^{21}$ ion (Fig. $3 a$ ). By comparison, the

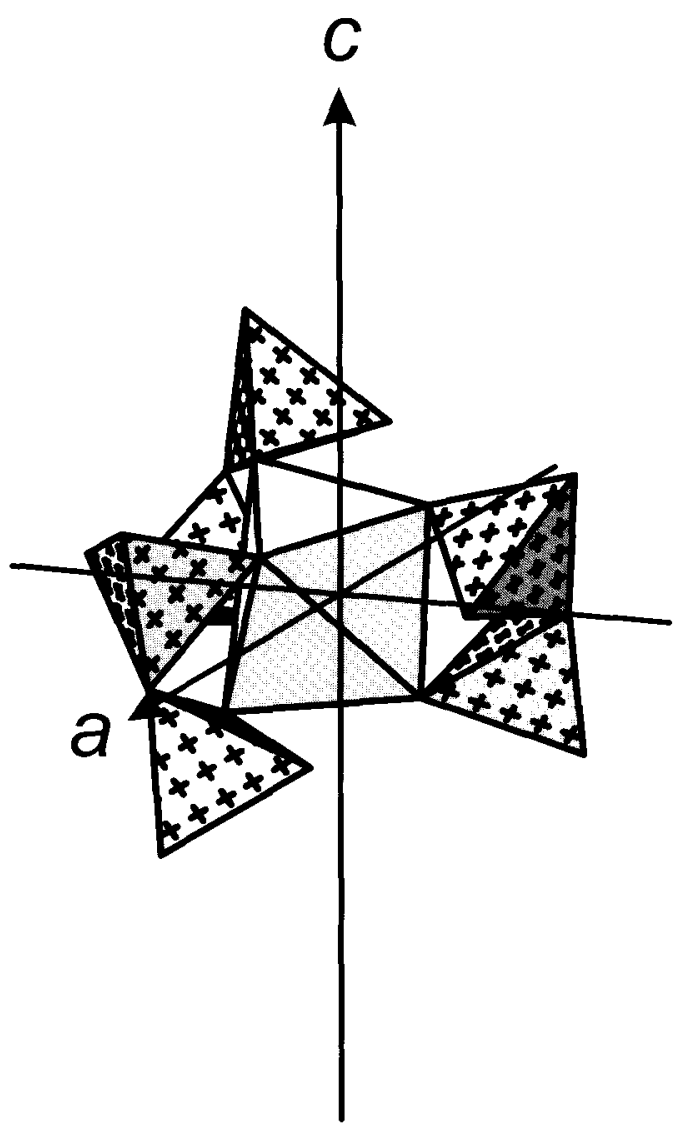

FIG. 2. The crystal structure of barysilite: view of the structural unit built of the distorted $\mathrm{MnO}_{6}$ polyhedron ( $\mathrm{Mn}$ at $0,0,0.25$ ) corner-linked to the disilicate group. (Note: the $c$ axis shown is halved). All drawings were done using ATOMS (Shape Software, 1999). 
a

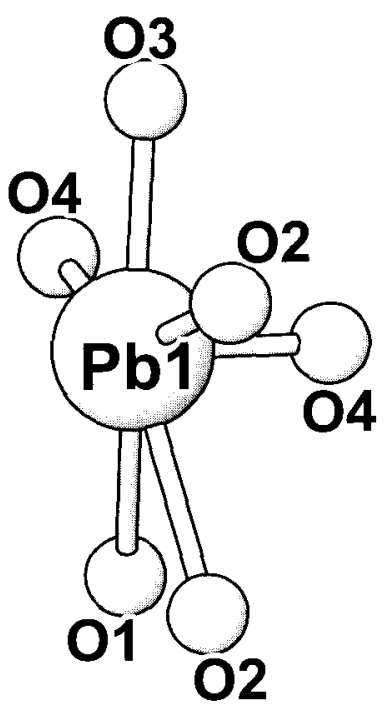

b

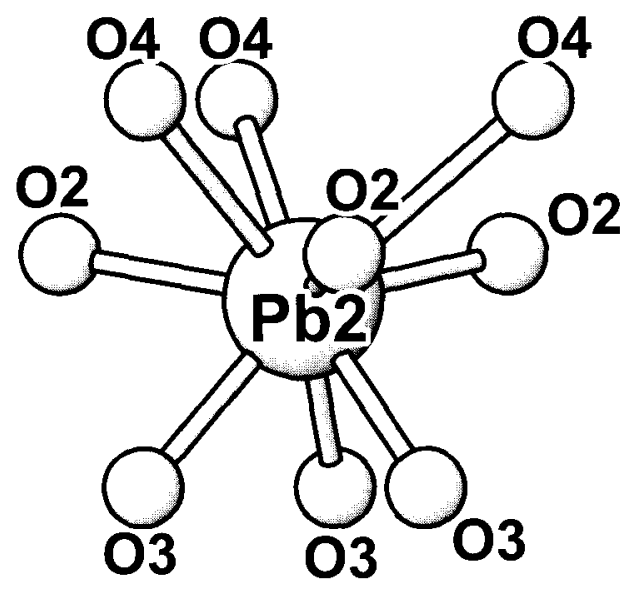

FIG. 3. The very different coordination polyhedra about $\mathrm{Pb} 1(a)$ and $\mathrm{Pb} 2(b)$ in the structure of barysilite from Garpenberg Norra.

$[6+3]$-coordinated $\mathrm{Pb} 2$ site is fairly regular, with $\mathrm{Pb}-\mathrm{O}$ distances of $2.540(4)(3 \times), 2.674(5)(3 \times)$ and $3.098(5)(3 \times) \AA$ (Fig. $3 b$ ). The earlier structure determination of Lajzérowicz (1965) gives an incorrect description of the $\mathrm{Pb} 2$ coordination, because the coordinates of the $\mathrm{O}$ atoms were of low precision and because the $\mathrm{Pb}-\mathrm{O}$ bond lengths were wrongly calculated; the reported coordinates of both $\mathrm{Pb}$ atoms, however, agree very well with those found in the present study.

The structural formula of barysilite-type compounds is $\mathrm{Pbl}_{6} \mathrm{~Pb}_{2} \mathrm{M}^{2}\left(\mathrm{Si}_{2} \mathrm{O}_{7}\right)_{3}$. Although previous authors concluded that cationic substitution is possible on the $M$ site, but not on either the
$\mathrm{Pb} 1$ or $\mathrm{Pb} 2$ site, Schmidt et al. (1982, 1983) provided some evidence that certain divalent cations can also substitute to a certain degree for $\mathrm{Pb} 2$. According to the present refinement model for barysilite, the $\mathrm{Pb} 2$ site contains $\sim 10 \%$ of $\mathrm{Ca}$ replacing $\mathrm{Pb}$ (refined occupancy: $\left.\mathrm{Pb}_{0.909(3)} \mathrm{Ca}_{0.091}\right)$. Our EMPA data indicate, however, that both $\mathrm{Ca}$ and $\mathrm{Ba}$ are probable minor substituents of $\mathrm{Pb} 2$. The preference of $\mathrm{Ca}$ for the $\mathrm{Pb} 2$ site, and not the $\mathrm{Mn}$ site, is indicated by a mean $\mathrm{Pb} 2-\mathrm{O}$ distance which is closer to that commonly observed for $\mathrm{Ca}-\mathrm{O}$ bonds.

Schmidt et al. (1983) analysed the behaviour of refined unit-cell parameters of synthetic powder samples with compositions along the three solid-

$\mathrm{T}_{\mathrm{ABLE}}$ 5. Crystal data reported for barysilite, $\mathrm{Pb}_{8} \mathrm{Mn}\left(\mathrm{Si}_{2} \mathrm{O}_{7}\right)_{3}$.

\begin{tabular}{llll}
\hline$a(\AA)$ & $c(\AA)$ & $V\left(\AA^{3}\right)$ & Reference \\
$-9.804(1)$ & $38.416(8)$ & $3197.8(8)$ & This work (single-crystal data) \\
$9.806(1)$ & $38.380(7)$ & 3196.1 & Schmidt et al. (1983) \\
$9.80(1)$ & $38.35(5)$ & 3190.8 & Bilihardt (1969); ICDD 23-404 \\
9.821 & 38.38 & 3205.9 & Ito and Frondel (1967); ICDD 20-714 \\
$9.821(5)$ & $38.38(6)$ & 3205.9 & Lajzérowicz (1965); ICDD 71-2178, 74-2289 \\
\hline
\end{tabular}


solution series $\mathrm{Pb}_{8} \mathrm{Cu}\left(\mathrm{Si}_{2} \mathrm{O}_{7}\right)_{3}-\mathrm{Pb} \mathrm{P}_{8} \mathrm{~Pb}\left(\mathrm{Si}_{2} \mathrm{O}_{7}\right)_{3}$, $\mathrm{Pb}{ }_{8} \mathrm{Cd}\left(\mathrm{Si}_{2} \mathrm{O}_{7}\right)_{3}-\mathrm{Pb}_{8} \mathrm{~Pb}\left(\mathrm{Si}_{2} \mathrm{O}_{7}\right)_{3}$ and $(\mathrm{Pb}, \mathrm{Ca})_{8} \mathrm{Ca}\left(\mathrm{Si}_{2} \mathrm{O}_{7}\right)_{3}-\mathrm{Pb}{ }_{8} \mathrm{Ca}\left(\mathrm{Si}_{2} \mathrm{O}_{7}\right)_{3} \ldots$ $\mathrm{Pb}_{8} \mathrm{~Pb}\left(\mathrm{Si}_{2} \mathrm{O}_{7}\right)_{3}$. They concluded that $\mathrm{Cu}, \mathrm{Cd}$ and $\mathrm{Ca}$ can all completely replace $\mathrm{Pb}$ at the $M$ site, but that only $\mathrm{Ca}$ can partially replace $\mathrm{Pb} 2$ atoms. The most Ca-rich barysilite synthesized by Schmidt et al. (1983) has the approximate composition $\mathrm{Pb}_{6}\left(\mathrm{~Pb}_{0.84} \mathrm{Ca}_{1.16}\right)_{22.00} \mathrm{Ca}\left(\mathrm{Si}_{2} \mathrm{O}_{7}\right)_{3}$. The present single-crystal study confirms the conclusions of Schmidt et al. (1983), and is the first direct proof that not only the $M$ site in barysilite-typc $\mathrm{Pb}_{8} M\left(\mathrm{Si}_{2} \mathrm{O}_{7}\right)_{3}$ compounds can be replaced by divalent cations. Any replacement of $\mathrm{Pb}$ at the very irregularly-coordinated $\mathrm{Pbl}$ site (with a stereochemically-active lone pair) would appear unlikely. Single-crystal structure refinements of further $\mathrm{Ca}-, \mathrm{Sr}-$ or Ba-rich barysilites are necessary to detcrmine the exact solubility limits and their dependence on temperature of formation. The detection of a hypothetical natural Ca-rich barysilite with $\mathrm{Ca}>\mathrm{Pb}$ on the $\mathrm{Pb} 2$ site would obviously lead to nomenclature complications. As far as these substitutional limits arc concerned, it is noteworthy that according to Billhardt (1969) intermediate members of the theoretical solid solution series $\mathrm{Pb}_{8} \mathrm{Mn}\left(\mathrm{Si}_{2} \mathrm{O}_{7}\right)_{3}-$ $\mathrm{Pb}{ }_{8} \mathrm{~Pb}\left(\mathrm{Si}_{2} \mathrm{O}_{7}\right)_{3}$ could not be prepared; he was only able to synthesize "two phases of different "barysilites".
The substitution of $\mathrm{Pb}$ by $\mathrm{Cd}, \mathrm{Ba}$ and $\mathrm{Sr}$ in synthetic $\mathrm{Pb}_{3} \mathrm{Ge}_{2} \mathrm{O}_{7}$ ('lead germanate barysilite') was investigated by Salnikow et al. (1979) using $\mathrm{X}$-ray powder diffraction. They found that up to $25 \%$ of the $\mathrm{Pb}$ atoms can be substituted by $\mathrm{Sr}$ without change in structure. This indicates a $\mathrm{Pb}: \mathrm{Sr}$ ratio as low as $3: 1$ by comparison with the ratio of $8: 1$ in the $\mathrm{Pb}_{8} \operatorname{Sr}\left(\mathrm{Ge}_{2} \mathrm{O}_{7}\right)_{3}$ end-member, and suggests a formula $\mathrm{Pb}_{6}\left(\mathrm{~Pb}_{0.75} \mathrm{Sr}_{1.25}\right)_{\Sigma 2.00} \mathrm{Sr}$ $\left(\mathrm{Ge}_{2} \mathrm{O}_{7}\right)_{3}$. Because the germanate barysilites probably have a more open framework, a higher substitution level than in silicate barysilites appears possible.

The single-crystal unit-cell parameters refined here, $a=9.804(1), c=38.416(8) \AA, V=$ $3197.8(8) \AA^{3}$ (hexagonal setting), are fairly similar to those given previously for both natural and synthetic samples (see compilation of available crystal data in Table 5), although the $c$ parameter appears slightly large by comparison The minor $\mathrm{Ca}, \mathrm{Ba}$ and $\mathrm{Mg}$ contents detected by EMPA certainly influence these parameters to some extent.

Calculated bond-valence sums for the atoms in barysilite are given in Table 4 . These values were calculated using the parameters of Brese and $\mathrm{O}^{\prime}$ Keeffe (1991) for $\mathrm{Si}-\mathrm{O}$ and $\mathrm{Mn}-\mathrm{O}$ bonds, and the revised parameters of Krivovichev and Brown (2001) for $\mathrm{Pb}^{2+}-\mathrm{O}$ bonds which take into account the well-known high variability of $\mathrm{Pb}^{2+}$ environ-

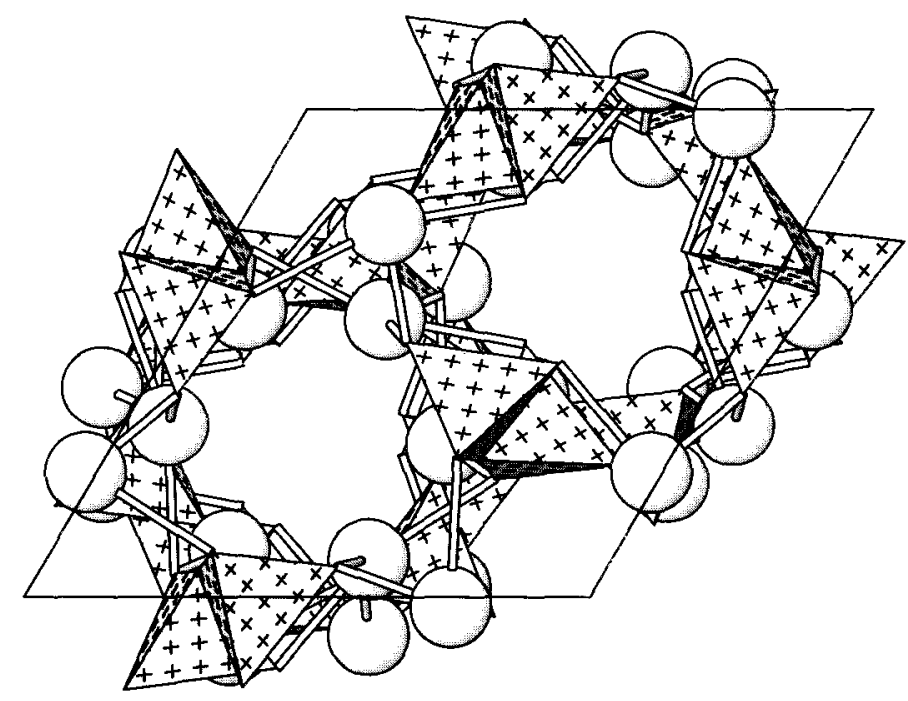

FIG. 4. View of the structure along [001], showing the framework with composition $\left[\mathrm{Pb}_{2} \mathrm{Si}_{2} \mathrm{O}_{7}\right]^{2}$ and the infinite channels parallel to [001]. These channels are filled with $\mathrm{Pb} 2$ and $\mathrm{Mn}$ atoms (see text). The unit cell is also outlined. 


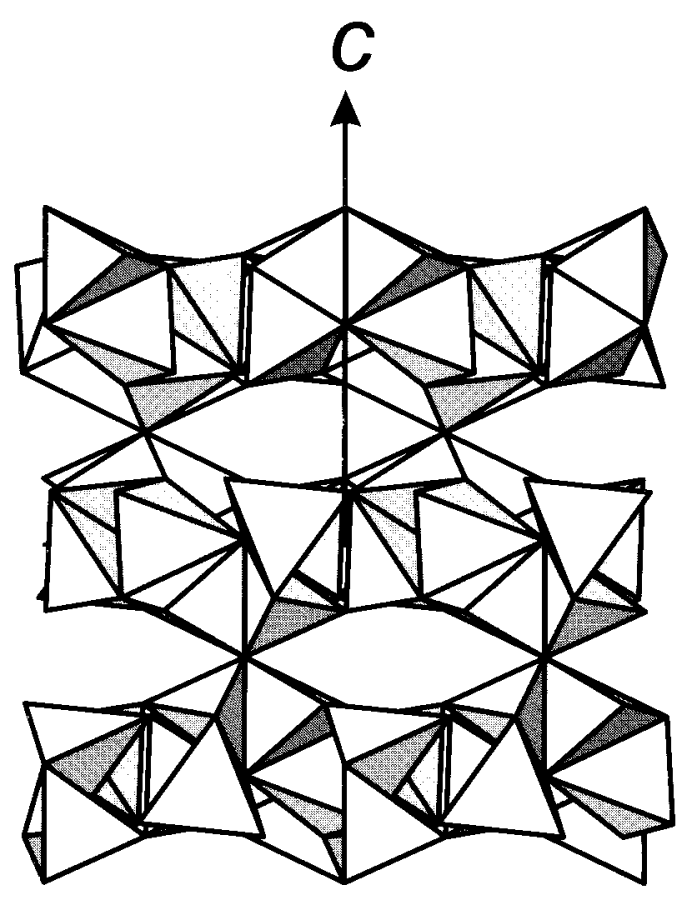

FIG. 5. An alternative description of the barysilite structure showing the connectivity between $\mathrm{O} 2 \mathrm{M}_{4}$ and $\mathrm{O}_{3} M_{4}$ tetrahedra which form an intricate framework hosting flattened voids (view along [010]; the direction of the $c$ axis is indicated; $\mathrm{Ol}$ and $\mathrm{O} 4$ atoms have been omitted).

ments. The bond-valence sums for Si (3.93 v.u.), $\mathrm{Mn}$ (1.85 v.u.), Pbl (1.94 v.u.) and Pb2 (1.92 v.u.) are in reasonable agreement with ideal values. When the parameters of Brese and O'Keeffe (1991) are used for the $\mathrm{Pb}^{2+}-\mathrm{O}$ bonds, the calculated sums for $\mathrm{Pbl}$ and $\mathrm{Pb} 2$ (2.15 and 1.81 v.u., respectively), show less agreement with expected values. Bond-valence sums for the four O atoms, 1.93, 1.90, 1.97 and 1.87 v.u., are close to the ideal values.

\section{Connectivity}

The complicated connectivity of the barysilite structure is characterized by isolated $\mathrm{Si}_{2} \mathrm{O}_{7}$ disilicate groups which are linked by the irregularly coordinated $\mathrm{Pbl}$ atoms to form a three-dimensional framework with the composition $\left[\mathrm{Pbl}_{2} \mathrm{Si}_{2} \mathrm{O}_{7}\right]^{2-}$. As shown in Fig. 4, this framework hosts infinite channels parallel to
[001] in which the more regularly coordinated $\mathrm{Pb} 2$ atoms, the $\mathrm{Mn}$ atoms and vacant positions are located in an alternating sequence ... Pb2-Mn$\mathrm{Pb} 2-\mathrm{Vac}-\mathrm{Vac}-\ldots$. The mean channel diameter in barysilite is considerably smaller than in $\mathrm{Pb}_{8} \mathrm{~Pb}\left(\mathrm{Si}_{2} \mathrm{O}_{7}\right)_{3}$ (cf. also Harnik, 1972).

An instructive alternative description of the atomic arrangement is possible when considering the linkage of more or less regular $\mathrm{OM}_{4}(M=\mathrm{Pb}$, $\mathrm{Mn}, \mathrm{Si}$ ) tetrahedra (cf. Krivovichev et al., 1998, and Krivovichev and Filatov, 1999 a,b). Both O2 and $\mathrm{O} 3$ form such tetrahedra whereas $\mathrm{O} 1$ and $\mathrm{O} 4$, which are connected to $2 \mathrm{Si}$ and $2 \mathrm{~Pb}$ (at $2 \mathrm{x}$ $3.09 \AA$ ), and $1 \mathrm{Si}$ and $3 \mathrm{~Pb}$ (at $2.17-3.08 \AA$ ), respectively, would form very distorted $\mathrm{OM}_{4}$ 'tetrahedra'. Figure 5 shows $\mathrm{O} 2 M_{4}$ and $\mathrm{O}_{3} M_{4}$ tetrahedra which are connected by both edges and corners to form an intricate, somewhat layered framework hosting flattened voids.

\section{Acknowledgements}

Prof. H. Effenberger provided valuable comments on the manuscript. This paper was partly written while the first author (UK) was supported financially by a Research Fellowship of the DFG (German Science Foundation).

\section{References}

Allen, R.A., Lundström, I., Ripa, M., Simeonov, A. and Christofferson, H. (1996) Facies analysis of a $1.9 \mathrm{Ga}$ continental margin, back-are felsic caldera province with diverse $\mathrm{Zn}-\mathrm{Pb}-\mathrm{Ag}-(\mathrm{Cu}-\mathrm{Au})$ sulfide and $\mathrm{Fe}$ oxide deposits, Bergslagen region, Sweden. Economic Geology, 91, 979-1008.

Billhardt, H.W. (1969) Synthesis of lead pyrosilicate and other barysilite-like compounds. American Mineralogist, 54, 510-521.

Bordcaux, D. and Lajzérowicz, J. (1969) Synthèse de la barysilite $\mathrm{Pb}_{3} \mathrm{Si}_{2} \mathrm{O}_{7}$. Bulletin de la Societé Française de Minéralogie et Cristallographie, 92, 383-385 (in French).

Brese, N.E. and O'Kceffe, M. (1991) Bond-valence parameters for solids. Acta Crystallographica. B47, 192-197.

Chen, S., Zhao, B., Jak, E. and Hayes, P.C. (2001) Experimental study of phase cquilibria in the $\mathrm{PbO}-$ $\mathrm{MgO}-\mathrm{SiO}_{2}$ system. Metallurgical and Materials Transactions, 32B, $11-16$.

Dunn, P.J. (1985) The lead silicates from Franklin, New Jersey: occurrence and composition. Mineralogical Magazine, 49, 721-727.

Firsov, A.V., Bush, A.A. and Venevtsev, Yu.N. (1984) Growth and study of $\mathrm{MPb}_{8}\left(\mathrm{Ge}_{2} \mathrm{O}_{7}\right)_{3}(\mathrm{M}=\mathrm{Ba}, \mathrm{Cd}$. 


\section{U. KOLITSCH AND D. HOLTSTAM}

$\mathrm{Zn}$ ) with the barysilite structure. Izvestiva Akademii Nauk SSSR, Neorganichestie Materialy, $\mathbf{2 0}$, 115-119 (in Russian).

Glasser, F.P. (1964) New data on barysilite. American Mineralogist, 49, 1485-1488.

Grensman, F., Kalinowski, M.P. and Sandström, F. (2001) Garpenberg Norra. Litofilen, 18, 26-46 (in Swedish)

Harnik, A.B. (1972) Structural chemistry of barysilitetype compounds $\mathrm{XY}_{2}\left(\mathrm{~Pb}_{2} \mathrm{Si}_{2} \mathrm{O}_{7}\right)_{3}$. American Mineralogist, 57, 277-281.

Holtstam, D., Gatedal, K., Söderberg, K. and Norrestam, R. (2001) Rinmanite, $\mathrm{Zn}_{2} \mathrm{Sb}_{2} \mathrm{Mg}_{2} \mathrm{Fe}_{4} \mathrm{O}_{14}(\mathrm{OH})_{2}$, a new mineral species with a nolanite-type structure from the Garpenberg Norra mine, Dalarna, Sweden. The Canadian Mineralogist, 39, 1675-1683.

Ito, J. and Frondel, C. (1967) Syntheses of lead silicatcs: larsenite, barysilite, and related phases. American Mineralogist, 52, 1077-1084.

Jonsson, E. and Broman, C. (1998) Fluid inclusion studies of hydrated $\mathrm{Mn}$ arsenates and associated minerals from the Långban mine, Sweden. Abstracts \& Programme, IMA $17^{\text {th }}$ General Meeting. Toronto. Ontario, Canada. August 10-14, A32.

Kalinowski, M.P. (1996) Rambergite, a now polymorph of $\mathrm{MnS}$ with hexagonal structure. GFF, 118 , A53-A54.

Krivovichev, S.V. and Brown, l.D. (2001) Are the compressive effects of encapsulation an artifact of the bond valence parameters? Zeitschrift für Kristallographie, 216, 245-247.

Krivovichev, S.V. and Filatov, S.K. (1999a) Metal arrays in structural units based on anion-centered metal tetrahedra. Acta Crystallographica, B $\mathbf{5 5}$, 664-676.

Krivovichev, S.V. and Filatov, S.K. (1999b) Structural principles for minerals and inorganic compounds containing anion-centered tetrahedra. American Mineralogist, 84, 1099-1106.

Krivovichev, S.V., Filatov, S.K. and Semenova, T.F. (1998) Types of cationic complexes based on oxocentred tetrahedra $\left[\mathrm{OM}_{4}\right]$ in the crystal structures of inorganic compounds. Russian Chemical Reviews, $67,137-155$.

Lajzérowicz, J. (1965) Etude par diffraction des rayons $\mathrm{X}$ et absorption infra-rouge de la barysilite, $\mathrm{MnPb}_{8} \cdot 3 \mathrm{Si}_{2} \mathrm{O}_{7}$, et de composés isomorphes. Acta Crystallographica, 20, 357-363.

Michoulier, J. (1967) E.P.R. spectrum of the manganese(II) ion in pyrosilicates and pyrogermanates which are barysilite isomorphs. Proc. Colloq. AMPERE, 14, 287-294 (in French). [not seen; abstract from Chemical Abstracts]

Nysten, P., Holtstam, D. and Jonsson, E. (1999) The Långban minerals. Pp. 89-183 in: Langban - The Mines, their Minerals, Geology and Explorers (D.
Holtstam and J. Langhof, editors). Swedish Museum of Natural History and Raster Förlag, Stockholm \& Chr. Weise Verlag, Munich, Germany.

Otto, H.H. (1983) Crystal data for rhombohedral lead germanate $\left(\mathrm{Pb}_{3}\left[\mathrm{Ge}_{2} \mathrm{O}_{7}\right]\right)$ isotypic with $\mathrm{Pb}$-barysilite. Journal of Applied Cnstallographv, 16, 430 .

Otwinowski, Z. and Minor, W. (1997) Processing of $X$-ray diffraction data collected in oscillation mode. Pp. 307-326 in: Methods in Enzymology, Volume 276: Macromolecular Crystallography A (C.W. Carter, Jr, and R.M. Swect, editors), Academic Press, London

Petter, W. and Harnik, A.B. (1971) Der Strukturtyp des Barysilit, $\mathrm{XY}_{2}\left(\mathrm{~Pb}_{2} \mathrm{Si}_{2} \mathrm{O}_{7}\right)_{3}$. Fortschritte der Mineralogie, 49, 39-40 (in German).

Petter, W., Harnik, A.B. and Keppler, U. (1971) Dic Kristallstruktur von Blei-Barysilit, $\mathrm{Pb}_{3} \mathrm{Si}_{2} \mathrm{O}_{7}$. Zeitschrift für Kristallographie, 133, 445-458 (in German).

Salnikow, V., Banik, G., Ettmayer, P. and Lux, B. (1979) Die Substituierbarkeit von Blei in $\mathrm{Pb}_{3} \mathrm{Ge}_{2} \mathrm{O}_{7}$ durch $\mathrm{Cd}$, Sr und Ba. Monatshefte fïr Chemie, 110, $755-758$ (in German).

Sandecki, J. (1983) A textural study of pyrite, sphalerite and galena from Garpenberg Norra, south central Sweden. Geologiska Föreningens i Stockholm Förhandlingar, 105, 213-222.

Schellhorn, M. (1987) Barysilit $\mathrm{Pb}_{8} \mathrm{Mn}\left[\mathrm{Si}_{2} \mathrm{O}_{7}\right]_{3}-$ ein weiterer Neufund aus dem Haldenmaterial der chemaligen Grube Glücksrad / Oberschulenberg. Aufschluss, 38, 339-340 (in German).

Schmidt, U., Breuer, K.H. and Eysel, W. (1982) Kristallchemie der Barysilite. Zeitschrift für Kristallographie, 159, $111-113$ (in German).

Schmidt, U., Breuer, K.H. and Eysel, W. (1983) Crystal chemistry of barysilite-type compounds. Neues Jahrbuch für Mineralogie, Monatshefte, 227-235.

Shannon, E.V. and Berman, H. (1926) Barysilite from Franklin Furnace, New Jersey. American Mineralogist, 11, 130-132.

Shape Software (1999) ATOMS for Windows and Macintosh V5.0.4. Kingsport, TN 37663, USA

Sheldrick, G.M. (1997a) SHELXS-97, a program for the solution of crystal structures. University of Göttingen, Germany.

Sheldrick, G.M. (1997b) SHELXL-97, a program for crystal structure refinement. University of Göttingen, Germany.

Sjögren, A. and Lundström, C.H. (1888) Om barysilit, ett förr ej uppmärksammat mineral frản Harstigen. Öfersigt af Kungl. Vetenskapsakademiens Handlingar, 45, 7-10 (in Swedish).

Vivallo, W. (1984) The metamorphism of the supracrustal rocks at Garpenberg, south central Sweden. Geologiska Föreningens i Stockholm Förhandlingar, 106, 257-267. 
BARYSILITE FROM GARPENBERG NORRA

Wittcrn, A. (1994) Sekundärmineralien durch Feuersetzen in Oberschulenberg, Bönkhausen, Bleialf und Badenweiler. Aufschluss, 45, 36-42 (in German).

Yeates, H. (1991) The lead silicate minerals of Franklin,
New Jersey: An SEM survey. Mineralogical Record, 22, 273-278.

[Manuscript received 2 October 2001: revised 22 February 2002] 